\title{
DIE INTEGRASIE VAN HUMORISTIESE TEKSTE IN DIE OPLEIDING VAN TAALONDERWYSSTUDENTE BINNE 'N KONSTRUKTIVISTIESE PARADIGMA
}

\author{
Estelle Kruger \\ Universiteit van Stellenbosch
}

Die artikel beskryf 'n gevallestudie waarin humoristiese tekste in die onderrig van Afrikaans aan onderwysstudente geïntegreer is. Die betrokke navorsingsprogram is gebaseer op ' $n$ onderrigprogram wat binne 'n konstruktivistiese paradigma ontwerp en aangebied is. Ná 'n literatuuroorsig van bestaande navorsing wat die aanwending van humor in onderrigsituasies regverdig, word die navorsingsmetode binne 'n kwalitatiewe raamwerk bespreek. Verskillende fases van die onderrigprogram geniet aandag, aangevul deur voorbeelde van onderrigmateriaal en -vrae om die leergebeure te fasiliteer. Laastens volg 'n bespreking van bevindinge wat uit die navorsingsprogram gespruit het, met spesifieke verwysing na die waarde van die skryf van limerieke en parodieë, asook webgebaseerde rolspeldebatte en virtuele kletskamers as deel van rekenaarondersteunde taalonderrig. Ter afronding word die deelnemende studente se refleksie en kommentaar op die onderrigprogram ook in aanmerking geneem.

This article describes a case study in which humorous texts have formed part of the method of teaching Afrikaans course for education students. This particular research focuses on a teaching programme conceptualised and executed within a constructivist paradigm. A literature review of research on the use of humour in teaching purposes is followed by a description of the qualitative methodology used. Specific examples of the educational material used in the different phases of the teaching programme and the questions posed to facilitate the learning process are then provided. This is followed by a discussion of the results of the research programme, focusing on the value of writing limericks and parodies, as well as on web-based role-play and chatrooms forming part of computer-assisted language teaching. The article ends with reflection and commentary by the education students who participated in the research programme.

Kernbegrippe: gevallestudie, humoristiese tekste, konstruktivistiese leerteorieë, kwalitatiewe navorsing, limeriek, parodie, refleksie, rekenaarondersteunde taalonderrig, taalonderrig, virtuele klaskamer, webgebaseerde rolspeldebat

Keywords: case study, computer assisted language learning, constructivist learning theories, humorous texts, language teaching, limerick, parody, qualitative research, reflection, virtual classroom, web-based role-play 


\section{INLEIDING EN AGTERGROND}

Hierdie artikel spruit uit 'n kwalitatiewe navorsingsprogram wat ek in 2004 met dertien onderwysstudente aan die Universiteit Stellenbosch gevolg het om aan te toon hoe humoristiese tekste in die onderrig van Afrikaans geïntegreer kan word. Ek het die navorsing vanuit ' $n$ kwalitatiewe perspektief benader met die doel om studente en leerders se subjektiewe ervaring van die leerproses beter te verstaan. Terwyl die ondersoek aanvanklik eksploratief was, is die artikel uiteindelik beskrywend om 'n bespreking van 'n gevallestudie as spesifieke navorsingstrategie te bied.

Die uitkomsgebaseerde onderwysbeleid in Suid-Afrika stel 'n nuwe uitdaging in die hoër onderwys om aspirant-taalonderwysers eksplisiet aangaande konstruktivistiese en holistiese leerteorieë te onderrig, deur hulle ervaringsgerig op te lei. Dit is nie meer voldoende dat studente slegs inligting daaroor hoor, lees of memoriseer nie, want bestaande en gevestigde stelsels wat die modernisme steun, sal dit moeilik maak om beduidende veranderings aan te bring. Opleiding moet voorsiening maak vir geleenthede om te reflekteer, om bestaande praktyke en die epistemologie te bevraagteken, en die aanvaarding en implementering van nuwe visies moontlik te maak (Howard et al. 2000:461; Wes-Kaap Onderwysdepartement, 2006). Motivering vir hierdie argument kan gevind word in Britzman (1986, in Conle, 2000:55) se woorde:
$\ldots$ it is a well known and often discussed issue that teaching candidates keep re-enacting their institutional biographies, that is, the scripts about teaching and learning into which they were enculturated as students, unless they experience some kind of awareness of those scripts and begin to counter the parts of their practical knowledge they do not like.

Die leerders vir wie deelnemers aan die navorsingsprogram gaan onderrig gee, is adolessente wat volgens my as 'n hedendaagse manifestasie van Generasie X/Y/Z (ook genoem millenniërs, vgl. Kruger, 2007b) in Suid-Afrika gesien kan word. Hierdie generasie adolessente is gewoonlik (kwasi-) informasiegeletterd as gevolg van die toenemende beskikbaarheid van en blootstelling aan die elektroniese massakommunikasiemedia. Leerders (en onderwysstudente), is dikwels kinders van middelklas- of welgestelde ouers, afkomstig uit voorstede, word gevoed deur McDonald's, vind hul tydverdryf in rekenaarspeletjies en inkopiesentrums en is grootgemaak met behulp van televisie (Sacks, 1996:120).

Dit is veral die kulturele faktore (soos in die vorige paragraaf uitgelig) wat 'n belangrike rol sal speel in die integrasie van humoristiese tekste by taalonderrig. Hierdie faktore word nie in die huidige artikel bespreek nie, maar elders meer volledig deur Kruger (2006b) behandel. Wat wel hier as motivering dien, is dat die kurrikulum van Afrikaans in uitkomsgebaseerde onderwys ' $n$ verruiming van die leerinhoud meegebring het, met 'n moontlikheid dat kulturele komponente by alle aspekte van taalonderrig geïntegreer kan word. In die kurrikulumdokumente (Departement van Onderwys, 2002; 2003) word daar nie alleen gespesifiseer dat leerders moet kan reageer op die estetiese, emosionele, kulturele en sosiale waardes van tekste nie. Daar word ook van opvoeders verwag om voortdurend te konsentreer op die ontwikkeling van leerders se vermoë om kulturele en estetiese sensitiwiteit in verskillende sosiale kontekste te openbaar.

Om die gevallestudie in die tersaaklike navorsingsprogram te konseptualiseer en om die ontwikkeling van my persoonlike epistemologie eksplisiet te maak, het ek 'n literatuurstudie 
gedoen in die bronne tot my beskikking oor sowel konstruktivistiese leerteorieë en affektiewe onderwys, as oor die integrasie van kreatiwiteit en humoristiese tekste in taalonderrig (vgl. Kruger, 2006a). Ek het die konteks beskryf deur adolessensie as Generasie X/Y/Z (lees: millenniërs) te bespreek en 'n verband aan te toon tussen uitkomsgebaseerde onderwys, kommunikatiewe taalonderrig en taakgerigte taalonderwys.

In die artikel word daar eerstens gefokus op 'n literatuuroorsig oor die integrasie van humor in onderrig, en hoe dit die klaskameratmosfeer en leer kan beïnvloed. Daarna word aandag gegee aan die navorsingsmetode waaruit die verslag voortspruit, met 'n beskrywing van die onderrigprogram wat daarvan deel uitgemaak het. Ter afsluiting volg 'n bespreking van die navorsingsresultate.

\section{HUMOR EN ONDERRIG}

In hierdie afdeling toon 'n literatuuroorsig dat die navorsing van verskeie navorsers en opvoedkundiges reeds getuienis gelewer het dat humor as faktor die klaskameratmosfeer en leer positief kan beïnvloed.

Kher et al. (1999) beweer dat humor 'n waardevolle onderriginstrument is om 'n klaskameratmosfeer te skep wat leer interessanter maak en dit daarom ook bevorder. Hulle beklemtoon dat geskikte en gepaste humor onderlinge openheid en respek kan bewerkstellig. Genoemde navorsers verwys na die navorsingsgetuienis in verband met die verhouding tussen onderwyser en leerder, en hoe entoesiasme en humor aansteeklik kan wees. Onderwysers speel ' $n$ noodsaaklike rol om kreatiewe leeromgewings te skep. Die integrasie van humor en humoristiese tekste as 'n katalisator kan bydra om kommunikasie te bevorder en konflik te ontlont.

Benewens die feit dat humor in die vorm van grappe, raaisels, dubbelsinnighede, snaakse stories, humoristiese kommentaar, strokies, lawwe versies (soos limerieke) en kammaeksperimente in lesings, toetse of eksamenopdragte geïntegreer kan word, kan dit die leerder se waardering van die inhoud verhoog. Uit ondersoeke is dit duidelik dat leerders 'n voorkeur vir strokieshumor het en dat strokies in handboeke tot 'n ontspanne leeratmosfeer lei (Lyttle, 2001).

Die onderwyser se sin vir humor kan ook daartoe bydra dat leerders ontspan en minder angs ervaar, spesifiek in die geval van sogenaamde ingewikkelde vakke soos wiskunde, natuurwetenskap en statistiek (Bryant et al., 1979; Kher et al., 1999; Peters, 2003). Verskeie navorsers toon aan dat humoristiese tekste geïntegreer kan word om aandag, begrip, geheue en motivering te fasiliteer (Bryant et al., 1979; Rutkaus, 1981; Shade, 1996; McMahon, 1999; Nilsen \& Nilsen, 1999; Ruggieri, 1999; Cook, 2000; Minchew, 2001; Belz, 2002).

Lyttle (2001) meen dat onderwysers daarvan behoort kennis te neem dat ironiese humor meer doeltreffend is as spotprente en dat selfspottende ('self-effacing') humor die beste uitwerking het. Ook Berk (1998:47), 'n professor in statistiek aan die Johns Hopkins Universiteit, maak suksesvol van selfspot gebruik. Hy is van mening dat dit die studente (by implikasie, leerders) aanmoedig om hom as toeganklik te ervaar, waarskynlik omdat die magsverhouding tussen die student en dosent hierdeur ietwat gerelativeer word. Die integrasie van humoristiese tekste kan ook skaam studente en leerders aanmoedig om deel te neem, omdat dit hul vrees om foute te maak, verminder (Pollak \& Freda, 1997; Chiasson, 2002). Dit is wel ook waar dat die 
waardering van humor afhanklik is van leeftyd en die humor van adolessente (as sogenaamde millenniërs) word in meer besonderhede bespreek deur Kruger (2007b).

Humoristiese tekste moet sensitief gekies en geïntegreer word, veral omdat dit aanstootlik kan wees vir individue en groepe - spesifiek stereotiperinge ten opsigte van godsdiens, ras, politiek en geslag (Berk, 1998:44; Kher et al., 1999; White, 2001; Torok et al., 2004). Alderman en Popke se studie (2002) beklemtoon die gevaar dat humoristiese stereotipes die klaskameratmosfeer negatief kan beïnvloed en leerders kan vervreem, of ongelykheid kan veroorsaak. Veral die gebruik van sarkasme en skimpe as humoristiese pogings om leerders belaglik te laat lyk, te intimideer of subtiel te straf, kan teenproduktief wees (Rutkaus, 1981:17; Pollak \& Freda, 1997; Chiasson, 2002; White, 2001:346; Kirsh \& Kuiper, 2003:34; Torok et al., 2004). Tog bevind Torok et al. (2004:17) in hul studie dat voorgraadse studente sarkasme as een van hul drie hoofkeuses vir gepaste humor aangedui het. 'n Moontlike verklaring hiervoor is myns insiens die voorkeur van manlike adolessente vir absurde en aggressiewe humor (Ruch, 1999).

Alderman en Popke (2002) beskryf hoe hulle humoristiese films en televisieprogramme as onderrigmateriaal benut. Daarmee stel hulle leerders spesifiek aan verskillende waardes en perspektiewe bloot en stimuleer hulle die leerders om hul eie en ander se vanselfsprekende veronderstellings en lewens- en wêreldbeskouings krities te ondersoek. Die genoemde studie van Alderman en Popke (2002) lewer getuienis dat humoristiese tekste leerders (in dié geval, onderwysstudente) se kritiese denke kan ontwikkel: die inkongruensie en jukstaponering van verskeie teenstellende konseptualiserings in die stories dra daartoe by dat konvensionele sienings van die werklikheid uitgedaag en ondermyn word. Leerders se kognitiewe buigbaarheid ontwikkel, omdat hulle heen en weer tussen verskeie standpunte moet beweeg. Algemeen aanvaarde patrone wat in die samelewing voorkom, kan dus deur die humorervaring arbitrêr gesubjektiveer en gerelativeer word.

Weber (2000) gebruik taalspel (herhaling, oordrywing en onverwagte assosiasies, metafore en vergelykings) en humoristiese tekste uit outentieke mediatekste om leerders te stimuleer om krities oor hul wêreld te dink. Verder gebruik hy speelse skryfstyle soos die parodie, 'rap' en limerieke om leerders bekende en bestaande materiaal (polisieverslae, sprokies, klassieke verhale, sportverslae, skinderkolomme, koerantartikels) te laat herskryf, wat humor tot gevolg het. Ook Alderman en Popke se studie (2002) bevestig dat humor sowel die klaskamerkommunikasie kan bevorder en belangstelling kan verhoog, as studente se selfbeeld kan verbeter, en dat humor 'n openbare forum kan bied waarin politieke, sosiale en morele kwessies krities bespreek kan word.

Dat humoristiese tekste geïntegreer kan word om onderwysstudente (en leerders) die wêreld waarin hulle leef krities te laat beskou, impliseer dat daar in die taalonderrigsituasie rekening gehou behoort te word met die ontwikkeling van deelnemers se kulturele geletterdheid. Twee kulturele faktore wat die integrasie van humoristiese tekste in die klaskamerkonteks kan beïnvloed en nie in hierdie artikel bespreek word nie, is die geslag (gender) van die leerders as 'n kulturele-identiteitsvormer en adolessensie as kulturele manifestasie van Generasie X/Y/Z (lees: millenniërs). Vervolgens word die metode wat ek in die navorsingsprogram gebruik het, bespreek. 


\section{NAVORSINGSMETODE}

Babbie en Mouton (2001:281) se mening dat gevallestudies die intensiewe ondersoek van 'n enkele eenheid behels (hoewel daar meervoudige veranderlikes kan wees), het aanvanklik vir my 'n uitgangspunt gebied waarvolgens die navorsingsgebeure beskryf kon word (Kruger, 2006a). Mettertyd het dit geblyk dat die interaksie van die eenheid wat bestudeer word persoonlike onderrigepistemologie en -strategieë, asook die studente met wie gewerk is, insluit. Ook was dit duidelik dat die onderrigprogram wat deel uitgemaak het van die totale navorsingsprojek ten nouste betrokke is by die konteks waarbinne dit bestaan (uitkomsgebaseerde onderwysbeleid en adolessensie). In die laasgenoemde verband word daar in hierdie artikel eksplisiet gefokus op die aspirantonderwysers wat die vak Afrikaans gaan onderrig, en implisiet op die sekondêreskoolleerders wat deel van hierdie onderriggemeenskap uitmaak.

Aangesien ek binne 'n konstruktivistiese paradigma' ${ }^{1}$ onderrig gee en navorsing doen (Kruger, 2008), het ek gereelde joernaalinskrywings gebruik om uitvoerige aantekeninge oor die proses te maak. Al was dit nie aanvanklik duidelik presies wat die uitkoms van die navorsingsprojek sou wees nie, het Guba en Lincoln (1989, in Babbie \& Mouton 2001:275) se bespreking van die moontlikheid dat navorsingsontwerpe mettertyd kan ontwikkel, wel voldoende ondersteuning gebied:

$[C]$ onstructivists are unwilling to assume that they know enough about the time/context frame a priori to know what questions to ask. That is, it is not possible to pursue someone else's emic [sic] construction with a set of predetermined questions based solely on the enquirer's etic [sic] construction ... Another way to say this is that ... constructivists typically face the prospect of knowing what it is they don't know ... But as the design proceeds, the constructivist seeks continually to refine and extend the design - to help it unfold.

Die ontwerpbeginsels waarvolgens die navorsingsgebeure beskryf is, stem ooreen met die bespreking van Yin (1994) en Stake (1995) se werk oor gevallestudies as deel van kwalitatiewe navorsing (Babbie \& Mouton 2001:282). Die beginsels van gevallestudiebeskrywing wat in die navorsingsproses in ag geneem is, is dat dit prakties, probleemoplossend, eksperimenterend, reflekterend en evaluerend is. Babbie en Mouton (2001:282) se bespreking van die konseptualisering van die gevallestudie dien as riglyn, want dit is 'n weerspieëling van hoe hierdie navorsingsprojek ontwikkel het.

Ter wille van betroubaarheid en geldigheid in die kwalitatiewe ondersoek het ek veelvuldige databronne in die navorsingsgebeure gebruik (Lather 1986). Om die data in te samel, het ek die genoemde beginsels van die kwalitatiewe beskrywing van 'n gevallestudie geïmplementeer en van die hele proses rekord gehou. Die verskeidenheid van kwalitatiewe data wat ek gedokumenteer het, sluit die volgende in: geskrewe beskrywings van waarnemings van die hele proses; voorbeelde van humoristiese tekste wat ek in die onderrigprogram geïntegreer het; pikturale humoristiese tekste en onderwysstudente se limerieke; onderwysstudente se parodieë as produkte van die onderrigprogram; vraelyste om 'n globale profiel van studente se tipe belangstelling in humor aan die hand van bekende mediatekste te bepaal; 'n humorstylvraelys; semigestruktureerde onderhoude met aspirantopvoeders om hul waarneming en interpretasie van die effek van humoristiese tekste in die onderrig van Afrikaans op te teken, en die geskrewe refleksie van onderwysstudente oor die navorsingsgebeure om hul aandeel daarin te rapporteer. Verdere data het betrekking op 
vraelyste aan sowel portuurlesers as onderwysstudente om kulturele temas in die genoemde parodietekste te bepaal; vraelyste aan portuurlesers om hul resepsie van parodietekste te bepaal; onderwysstudente se onderrigprogramme aan die hand van humoristiese tekste by die skole waar hulle in Augustus 2004 vir skoolbesoek was; 'n uitgedrukte kopie van die hele virtuele rolspeldebat wat van WebCT afgelaai is; transkripsies van onderhoude sowel as mondelinge en geskrewe refleksies deur die aspirantopvoeders oor die onderrigprogram, hul eie ontwikkeling en die response van leerders by skole. Die analitiese strategie wat ek gebruik het om die data te ontleed, was teksanalise om patrone en temas te vind, te verduidelik en veralgemenings te maak.

Aangesien ek in hierdie navorsingsprogram primêr aandag gegee het aan 'n beskrywing van die interaksie tussen my en die aspirantopvoeders, het ek op 'n mikroperspektief van navorsing binne die opvoedkundige konteks gekonsentreer. 'n Mikroperspektief fokus op die interaksie tussen opvoeders en studente (lees ook: leerders). Die mikroanalise van hierdie spesifieke soort interaksie verhelder sowel die leeruitkomste as die gevolge van verskillende soorte leergeleenthede en -prosesse (Carr \& Kemmis 1986:21-22). Vervolgens bespreek ek die onderrigprogram wat deel was van die navorsingsgebeure.

\section{ONDERRIGPROGRAM AS NAVORSINGSGEBEURE}

Dit is belangrik om daarop te let dat die navorsingsgebeure bestaan het uit 'n onderrigprogram wat gelei het tot die insameling (generering) van data. Ter wille van die bespreking word ' $n$ onderskeiding gemaak, maar die twee dele van die program was ten nouste verweef. Gedurende 2004 het ek die betrokke studente aan die US in verskeie fases aan die onderrig van Afrikaans laat deelneem:

In die eerste fase het ek die studente blootgestel aan Bruegel se prent oor kinderspel en 'n parodie daarop (Medgyes, 2002). Hierna het ek 'n klasgesprek gelei oor die ooreenkomste tussen spel, kreatiwiteit en humor (McGhee, 1979). Daarna is die studente bekendgestel aan die konsep kulturele geletterdheid. Dit is die netwerk van agtergrondinligting wat essensieel is om te kan sin maak van die geskrewe woord (en ook van visuele representasies), dit wil sê om begrip te hê van wat geskryf (en visueel uitgebeeld) is. Kulturele geletterdheid stel mense volgens Combrink (1996:3) in staat om grappe, verwysings, assosiasies, metafore, ensovoorts, te snap.

Met die klasgesprek oor die ideologiese en materiële manifestasies van kultuur wou ek konsentreer op die feit dat humor 'n kulturele uiting is, en dat die skep, resepsie en waardering daarvan deur konteks (tyd, plek en gebeure) bepaal word. Aangesien die studente op daardie stadium pas teruggekom het van hul eerste skoolbesoeke, was die pikturale humor in 'n Comic School-legkaartprent (Kruger, 2006:350) 'n gepaste inleiding tot die klasgesprek oor die resepsie en produksie van humortekste. Hierdie legkaartprent is 'n visuele parodie met stereotipes, karikature en inkongruensie wat studente moontlik in die klaskamers ervaar het. Ek het eers die prent gesegmenteer sodat die verwysing na humor wat daarin voorkom beter in die klasgesprek hanteer kon word. Die vrae wat ek gebruik het om die humor in die prent te ontgin, was onder meer gerig op herkenning, inkongruensie (iets wat onlogies of onmoontlik is), taboe- en reëlverbreking, oordrywing, dilemma, ongewone optrede en enige ander elemente van situasionele humor (vgl. Van Niekerk, 2001). 
Studente het in 'n dinkskrum die volgende aktiwiteite genoem wat met die integrasie van hierdie prent in die onderrig van Afrikaans gepaard kan gaan:

- Hou 'n dinkskrum oor probleme wat in die klaskamer ontstaan as gevolg van reëls (eksplisiet of implisiet) wat oortree word en ontwerp 'n plan van aksie om dit reg te stel. Dit kan lei tot 'n goeie gesprek oor individuele verskille, algemene klasreëls en dissipline. Gerigte vrae stimuleer die leerders se kritiese denke en probleemoplossingsvaardighede.

- $\quad$ Noem die karakters van wie jy nie hou nie en motiveer jou stelling.

- Gee byname vir enige van die karakters; dink name uit vir die speletjies of aktiwiteite.

- Werk mondelinge instruksies uit oor hoe om van een plek in die klaskamer na 'n ander te beweeg, en neem die obstruksies in ag.

- Verbeel jou dat jy een van die karakters is en maak 'n dagboekinskrywing met sintuiglike beskrywings.

- Gee 'n kort beskrywing van karakters volgens die segmentnommer waarin hulle voorkom. Dit kan in 'n speletjie as 'n luisteroefening gebruik word.

- Raaisels kan bygevoeg word om te voorspel watter loopbane elke karakter sal volg.

- Byvoeglike naamwoorde en voorsetsels kan gesoek word om by elke beskrywing te pas.

- Leerders kan uitgedaag word om idiomatiese uitdrukkings en vergelykings in 'n woordeboek te soek wat by die situasies of karakters pas. 'n Vasvrakompetisie kan daaroor gehou word.

- $\quad$ Leerders kan 'n informele brief skryf om te vertel van 'n snaakse dag by die skool. 'n Dialoog tussen verskillende karakters met die gepaste taalgebruik kan uitgewerk en opgevoer word.

Ek het aan die hand van verskeie ander visuele en woordtekste op verskillende soorte humor gekonsentreer, naamlik woord-, situasie- en pikturale humor (Van Niekerk 2001; Verster 2003). Onder andere het ons in 'n klasgesprek Oom Oubaas van 7de Laan op SABC2 ${ }^{2}$ se parodiese gebruik van idiome bespreek (vgl. Genette 1997:17), sowel as Bruegel (c. 1588) se visuele parodieë (Vlaamse spreekwoorde, Cornew 1995:64). Ook Johan Combrink se woordspel in Kwinksinnig (1998) en 'Dit lol' in Bietjie Baie Bogtery van P.W. Grobbelaar en W. Jordaan (1980:10), asook stereotipes, karikature en dubbelsinnigheid in verskeie humoristiese tekste uit advertensies en ander massamediabronne (spotprente en grappies uit Die Burger en Huisgenoot) is as onderrigmateriaal gebruik. 


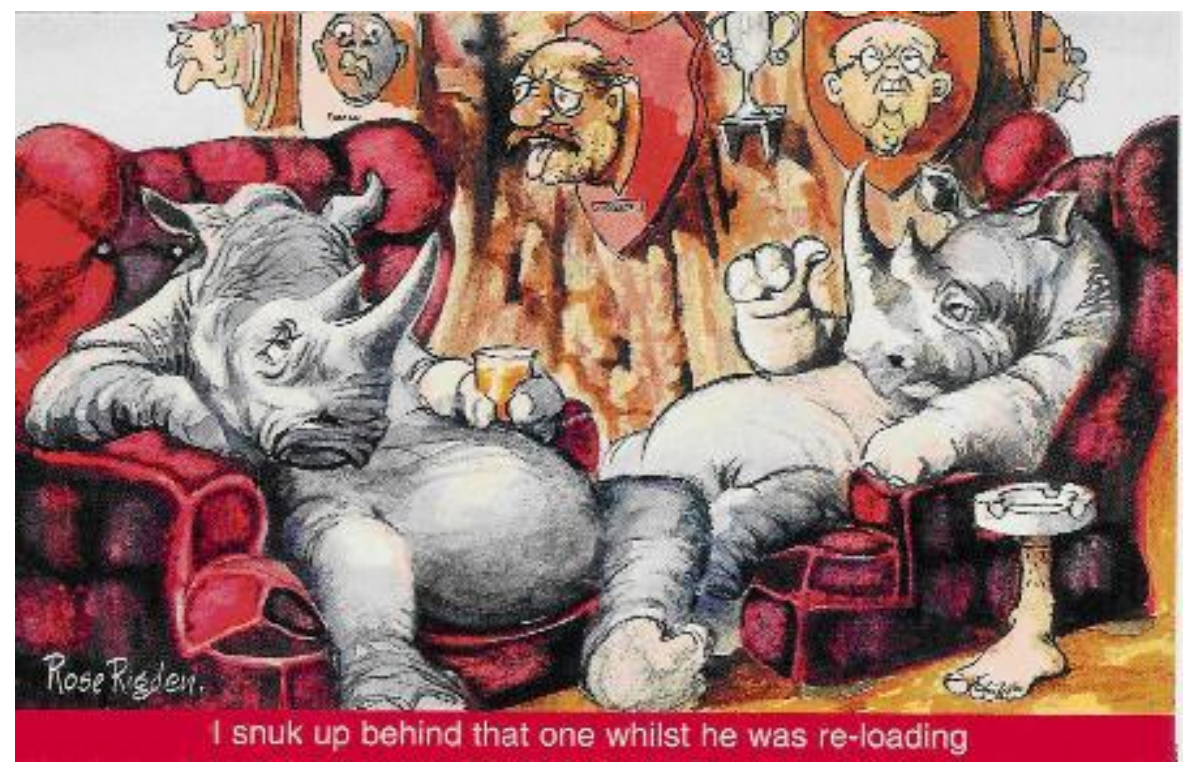

'n Jagter van Groot Buffelsbaai

Het stadig sy skietgoed gelaai

Toe trek iets hom plat

Sy koeëls het gespat

En nou kan ons almal net raai...

Die studente se eerste skryfopdrag was om in pare te werk en met die samelewing te spot deur die skryf van limerieke wat gebaseer is op visuele (ekologiese) parodieë in Wildside (Rigden 2001). Die vertrekpunt was voorskrifte, wenke en voorbeelde van Philip de Vos in Mallemeuleman (2004), asook elektroniese prikkels op Storiewerf (2000). 'n Voorbeeld van hierdie prent (Rigden, 2001:64) met die gepaardgaande limeriek is bo getoon (Kruger, 2006a:360). Daarna is die kenmerke en struktuur van sprokies aan die hand van 'n vloeidiagram bespreek en studente het in pare of groepies van drie hul eie sprokie gekies om te parodieer. Die opdrag het soos volg gelui:

- Kies ' $n$ bekende sprokie en verander die karakters, ruimte en tyd soos jy verkies;

- las hierdie dele aanmekaar en skep 'n parodie met 'n intrige wat in die konteks van jou huidige samelewing pas;

- $\quad$ spot in jou parodie met die samelewing soos wat jy wil.

Pretorius (1992:370-371) en Band (1990:179-180) se bespreking van die parodie is aan die studente voorgehou, sowel as voorbeelde van bestaande parodieë wat by hul gekose sprokies pas. Laasgenoemde kan gevind word in Revolting Rhymes van R. Dahl en Q. Blake (1982), Politically correct bedtime stories van J.F. Garner (1994), en Kat se Blad van P. de Vos en P. Grobler (1999).

Om die proses van kreatiewe denke te fasiliteer, het ek die studente bekendgestel aan Eberle (1982; vgl. ook Flack, 1997:126-7) se SCAMPER-tegnieke ${ }^{3}$, waarmee hulle karakters, plekke, voorwerpe, tyd en gebeure kon aanpas om te spot met iets of iemand in hul eie samelewingskonteks. Hierdie tegnieke kom ooreen met parodiestrategieë (Rose 1993:79; Hutcheon 1985:88) en satiriese wapens (Vosloo 2003:70).

Ten opsigte van die kreatiewe proses het ek in die ondersoek veral kennis geneem van literatuur oor Torrance $(1962 ; 1970 ; 2003)$ se nalatenskap van die meting van kreatiwiteit. 
Daarmee saam is ook gelet op Robertson (1980), Amabile (1983), Ruscio et al. (1998), sowel as op Baldwin (2001) se bespreking van aspekte van kreatiwiteit. In hierdie geval het dit veral betrekking gehad op taal wat ryk is aan metafore en simboliek, sintuiglikheid, 'n bewustheid van emosies en intuïsie, en pragmatiese probleemoplossingsvaardighede. In die onderrigproses het ek verskillende fases geïmplementeer om kreatiewe skryf te stimuleer:

- $\quad$ sensasie (intra- en interpersoonlike blootstelling aan die media en bewuswording van humor, gevoelens, assosiasies, herinneringe, gesprek, saamlag);

- eksplorasie en manipulasie (verkenning, inligting soek, toepassing van kategorieë, speel met idees, saamdink, breinskrums en idee-diagramme, SCAMPER-tegnieke, meervoudige intelligensie-aktiwiteite en take);

- $\quad$ inkubasie (stilte, meditasie, tyd tussen lesse, betrokkenheid by meganiese aktiwiteite waartydens die onderbewuste aan die werk is en na nuwe kombinasies soek);

- $\quad$ organisering (gebruik/verwerk inligting, beplan om te produseer);

- $\quad$ produksie (skryf parodie individueel);

- evaluering (assessering van 'n ander student se parodie, hersiening en redigering van eie parodie, mondelinge en skriftelike refleksie oor ervaring en moontlike gebruik in eie onderrig).

Die studente moes eers met behulp van nuwe idees wat hulle in pare of groepies van drie gegenereer het, 'n akrostigon skryf (Lochner 2005) - 'n gediggie aan die hand van die naam van hul sprokie. Menkveld (1990:350) noem dit naampoësie. Hulle gebruik dus die letters van die naam om nuwe versreëls te vorm. Hierdie gediggies is meestal sinloos, maar verwoord tog op 'n speelse manier reeds van die studente se gedagtes wat in die dinkskrum ontstaan het. Dit is dus ' $n$ soort sintese-oefening wat volg op die ontleding van die sprokie. 'n Voorbeeld daarvan is een wat deur die studente saamgestel is aan die hand van RAPONSIE:

Raponsie, Raponsie

Agter jou

Pantene-mure

O wee!

Nou waar is die gaatjie in jou borrel?

Sê my, waar?

In die boom?

Êrens, êrens moet ek soek vir die chemiese stroom.

Elke deelnemende aspirantopvoeder moes aan die einde van hierdie fase individueel 'n gepaste lesprogram met humoristiese tekste as onderriginstrument (volgens hul keuse) ontwerp en implementeer. Dit sou doeltreffende onderwys binne elke deelnemer se bepaalde onderrigkonteks verseker tydens hul skoolbesoeke in Julie en Augustus 2004.

As verdere opdragte in die eerste fase moes die studente mekaar se parodieë assesseer na gelang van 'n rubriek met kriteria vir kreatiwiteit. Al hierdie opdragte het deel uitgemaak van 'n uitgebreide deurlopende assesseringportefeulje. In 'n onderhoud wat aan die einde van die module met die studente oor humor gevoer is - voor hul blootstelling aan die gebruik van die rekenaar in taalonderrig - het ek die gesprek gestruktureer rondom alles wat in hierdie module aangeraak is, insluitende die refleksie en assessering. Hierdie onderhoud is opgeneem, getranskribeer en vir data-ontleding gebruik. 
Die tweede fase van die onderrigprogram het behels dat ek studente gedurende die tweede semester van 2004 aan die gebruik van die rekenaar in taalonderrig blootgestel het. Eerstens moes studente aan die begin van September 2004 'n rekenaarondersteunde taalonderrigprogram met pikturale humor aan die hand van Honiball se folklore vir Afrikaans as addisionele taal beoordeel. Dit sou geskied op grond van die beginsels van addisioneletaalonderrig nadat hulle blootgestel is aan Krashen (1985) se monitorteorie (Blacquière 1989; Black 1986; Botha 1989). Daarna moes hulle die genoemde rekenaarondersteunde taalonderrigprogram evalueer aan die hand van hierdie beginsels. Hierdie fase word in meer besonderhede beskryf deur Kruger (2007a).

Die derde (en laaste) fase van die onderrigprogram was gerig op studente se interaktiewe gebruik van 'n webgebaseerde rolspeldebat. Hulle moes aan die hand van 'n stereotiepe persona die wenslikheid (al dan nie) daarvan bespreek om Harry Potter-tekste as voorgeskrewe materiaal in huistaalonderrig te gebruik. Die insluiting van die rekenaar (in onder andere 'n rolspeldebat aan die hand van stereotipes) het uitstekende moontlikhede gebied om die studente bloot te stel aan 'n nuttige instrument wat vir huistaalonderrig gebruik kan word. In hierdie betrokke navorsingsprogram het ek stereotipes geskep om humor en letterkunde in 'n virtuele klaskamer met mekaar te integreer. Die studente se refleksie oor die virtuele rolspel is as deel van die data vir ontleding gebruik. Die bedoeling met die virtuele rolspeldebat was dat die stereotiepe rolle wat hulle moes inneem en 'uitleef', sou bydra tot die ontwikkeling van hul kritiese en kulturele geletterdheid, kreatiwiteit, humorgebruik en redeneervaardighede.

Vrae waaroor hulle as deelnemers binne die opvoedkundige konteks in hul onderskeie rolle moes redeneer, was of die Harry Potter-reeks vir die klassituasie geskik is, of dit vir leerders van Afrikaans as huistaal voorgeskryf kan word, en vir watter ouderdom dit gepas sou wees. Hulle kon ook debatteer oor waarom hierdie reeks juis in Afrikaans voorgeskryf moet word as daar reeds plaaslik soveel Afrikaanse jeugboeke van 'n hoë gehalte beskikbaar is. In 'n rolspeldebat oor die bogenoemde opvoedkundige dilemmas, wat met behulp van 'n sinchroniese kletskamerformaat op die universiteit se intranet op WebCT gevoer is, kon die studente kies watter rol hulle wou inneem. Die rekenaarkletskamer is opgestel volgens die beginsels van rolspel, argumentering en rekenaarondersteunde onderrig (Tompkins, 1998; Bell, 2001; Ip, Linser \& Naidu, 2001; Krish, 2001; Murphy \& Gazi, 2001; Simonneaux, 2001; Thorson, 2002; Liebowitz, 2002; Martin, Leberman \& Neill, 2002; Lynch, 2002; 2004).

Studente moes hulle volgens sekere gegewe rolle voorberei om as lede van 'n skoolbeheerraad 'n debat te voer oor die waarde (al dan nie) van die Harry Potter-boeke. Die rolle is doelbewus gestereotipeer en gestruktureer om kontroversiële standpunte wat bestaan in 'n (moontlik tipiese) alledaagse Afrikaanssprekende skool (soos in 2004) uit te beeld. Die volgende opsies het bestaan:

- Mev. Flowers was in die sestigerjare 'n hippie. Sy het intussen tot ander insigte gekom en haar tot die Christelike geloof bekeer. Sy wil nie hê haar kinders moet blootgestel word aan die New Age-ideologie nie.

- Ds. V. Room het sy kinders belet om die Harry Potter-reeks te lees, maar agtergekom dat hulle dit nietemin in die geheim verslind het. Hoewel hy nie self die boeke gelees het nie, het hy vermoed dat okkultisme daarin voorkom.

- Me. F. van Emmenis is die voorsitter van die Feministestudiegroep en sy dink Harry Potter is chauvinisties. 
- Mnr. Groenewald is die stigter van die Green Peace-beweging in Suid-Afrika. Sy jongste dogtertjie van tien kry nagmerries van 'Die beker vol vuur'.

- Mej. Maria Smit se ma het die Liewe Heksie-reeks geskryf. Sy dink fantasie is goed vir kinders, omdat dit hulle verbeelding stimuleer.

- Adv. F.E.F. le Roux is 'n skrywer van reeksboeke vir jongmense wat in die sestigerjare verskyn het.

- Bert E. Spier is die hoofseun en kaptein van die eerste rugbyspan en al wat hy lees is Bitterkomix. Hy wil graag 'n filmvervaardiger word.

- Mnr. F. Reud is 'n sielkundige en sy dogter is al twee keer vir kleptomanie behandel. Hy meen dat die reeks goed is vir kinders se emosionele en morele ontwikkeling.

- Mev. Telana Olkien is die sekretaresse van die skool en haar oudste seun (15) het vir die eerste keer in sy lewe begin lees sedert die Harry Potter-boeke verskyn het. Op die oomblik lees hy Lord of the Rings.

- Mev. Saartjie Choon is die skoonmaker by die skool en kan nie goed lees of skryf nie. Sy luister egter graag radio en kyk sepies op TV.

- Susan Koen is die hoofmeisie. Sy was 'n uitruilstudent by die VN se konferensie vir opkomende leiers. Sy wil graag 'n joernalis word en is 'n voorvegter vir menseregte.

- Sers. S. O'Kulis het 'n grondige studie oor Satanisme gedoen nadat etlike voorvalle daarvan in die skool voorgekom het.

- Prof. Frans Antasia is 'n kenner op die gebied van rillers as 'n subdomein van die letterkunde.

Daar was bepaalde probleme waaraan die studente in hul voorbereiding moes aandag gee en wat die leidende vrae in die kletskamer sou uitmaak. Dit was die feit dat die boeke aan die een kant wêreldwyd gewildheid geniet (Kruger, 2003a), in 55 tale beskikbaar is en ook in Afrikaans verkoop word, dat opvoedkundiges en bibliotekarisse dankbaar is dat iemand kinders weer aan die lees kon kry, en dat die skrywer, J.K. Rowling, sedert 2000 deur verskeie universiteite (Edinburgh, New Hampshire, Exeter, St Andrews) met eredoktorsgrade vereer is vir die skryf van die reeks. Aan die ander kant kry ouers vanuit fundamentalisties-Christelike kringe elektroniese e-posboodskappe met ernstige besware teen die bedenklike morele waardes en heksery wat in die boeke gepropageer word (Kruger, 2003a).

Ek het gedurende die verloop van die drie virtuele lesse sekere vrae gestel om die debat te stuur. Dit sou sorg dat die studente nie op een persoon se standpunt vashaak en te persoonlik raak in hul aanvalle op ander karakters nie (Lynch, 2004:112). Die volgende het aan bod gekom:

- Stel jouself (in jou rol of persona) aan die ander rolspelers voor en meld kernagtig wat jou standpunt ten opsigte van die onderwerp van bespreking is.

- Spreek die Harry Potter-boeke wel Afrikaanse kinders aan - is hulle ook 'brattish, selfish, consumerist, uncaring and greedy', en dus mense wat streef na materialisme en selfbevordering, soos wat een van die teenstanders van die boeke beweer?

- Watter boodskap bring die reeks oor menswaardigheid en morele keuses?

- Hoekom is almal so bang vir die boeke as mense wat by die Wicca-beweging betrokke is, en dus heksery beoefen, self meen dat die uitbeelding daarvan in die reeks oppervlakkig en onakkuraat is?

- Is die hele Harry Potter-reeks nie maar net 'n ekonomiese 'hype'-verskynsel wat ook mettertyd sal vervaag soos die Ninja Turtles nie?

- Betrek die boeke wel leerders se emosionele, intellektuele en verbeeldingsbehoeftes? 
- Kan die reeks hedendaagse tieners help om minder uitgelewer te wees aan die massamedia en 'n kapitalistiese verbruikersmentaliteit?

- Watter raad kan ons vir besorgde Christen-ouers gee wat agterkom dat hul kinders wel die boeke lees en/of die films gaan kyk?

- Is dit nie so dat baie Afrikaanssprekendes eintlik net te min kennis van fantasie as literêre genre het, en daarom die boeke wil verban nie?

- Hoe kan die reeks gebruik word om leerders meer krities bewus te maak van hul kulturele erfenis ten opsigte van fantasie regoor die wêreld?

- Wat sou die waarde van monsters, drake en hekse in stories wees?

In die dokumentasie van hierdie virtuele rolspeldebat en die studente se refleksie daaroor, is dit duidelik dat die debat 'n sterk humoristiese respons by die studente ontlok het (vgl. Lynch, 2004:177), veral omdat die stereotipering van rolle 'n motoriese moment van die gesprek was. In hul terugvoer meld die studente hoeveel hulle gelag het (veral vir die simplistiese bydrae van die karakter Saartjie Choon), hoe die debat hul kritiese en kreatiewe denke ontwikkel het omdat hulle binne 'n sekere rol moes standpunt inneem, en tog ook ander perspektiewe moes aanhoor wat hulle by hul eie redenering moes integreer (vgl. Ziv, 1984).

\section{BESPREKING}

Een van die doelstellings van my onderrigprogram was om in ooreenstemming met konstruktivistiese leerteorieë die rol van 'n begeleier en fasiliteerder in die onderrigproses te modelleer. Uiteindelik is dít die rol wat onderwysstudente as onderwysers moet inneem (Staatskoerant, 2000:15-16) om sowel die onderrig-, skryf- en assesseringsproses, as die refleksie daaroor te medieer. Daarby moes studente ook voortdurend oor die proses en hul ervaring daarvan, hul gedagtes daaroor en hul interpretasie daarvan reflekteer.

Die refleksie van die studente het die belang van die limeriek as oefening vir satire duidelik na vore gebring. Verder was dit 'n bruikbare aktiwiteit om studente bewus te maak van klankmanipulasie soos rym en ritme, en hulle te laat soek na sinonieme deur middel van assosiasies wat deur die pikturale humor gestimuleer is. Die oefening het ook met pret gepaard gegaan, sodat die studente nie gevoel het asof hulle besig was met 'n leeraktiwiteit nie. Tog het die studente in hul refleksie die mening uitgespreek dat dit goed sou wees om in soortgelyke onderrigprogramme meer geleentheid te skep vir terugvoer waar deelnemers na mekaar se limerieke kan luister. Die gediggies wat nie presies in die limeriekpatroon gepas het nie, kan beskou word as lawwe versies (De Vos, 2000) - ook 'n aanvaarde digvorm waarmee leerders kan eksperimenteer sonder die gewone bedreiging wat met kreatiewe skryftake gepaard gaan. Dit was ook opvallend dat heelwat studente daarvan melding gemaak het hoe hulle van mekaar verskil het, en dat nie almal maklik aan hierdie opdrag kan sáámwerk nie.

Die oogmerk wat ek met die parodie-skryfopdrag gehad het, was dat studente uitgebreide ervaring moes opdoen van die kreatiewe skryfproses en die assessering van 'opstelle'. Daarby moes hulle leer om op 'n verbeeldingryke manier te projekteer en uiting te gee aan hul eie waarneming en ervaring van die samelewing waarin hulle woon. Die skryf van die parodie het dus gedien as oefening om studente voor te berei om op 'n praktiese manier (vergelyk Kolb se konsep van ervaringsleer, 1984:38) die grondbeginsels van postmoderniteit te verstaan (Ermarth 1999:226). Dit kon deur die transformasie van hul eie skryfervaring plaasvind. 
Verder wou ek aan die studente 'n geleentheid bied om verskillende vorme van humoristiese tekste waaraan hulle in die onderrigprogram blootgestel is, toe te pas en te integreer.

Die temas wat ek in die parodieë gevind en bespreek het, was die invloed van die massamedia en ' $n$ verbruikersamelewing, studentekultuur, die Suid-Afrikaanse samelewing in 'n postapartheidfase, heteroglossia en kruiskulturele humor (Kruger, 2006a; 2006b). Sommige parodieë was ryk aan eietydse kulturele temas, ander minder geskakeerd of genuanseerd. Die verband tussen dekadensie, 'n verbruikersmentaliteit en die hedendaagse studentekultuur soos dit sigself in die onderwysstudente se parodieë gemanifesteer het, was onmiskenbaar. Dit kan moontlik toegeskryf word aan Raybin (1990:29) se idee dat studente as adolessente in 'n niemandsland van liminaliteit (oorgangsfase tussen kinderjare en volwassenheid, te midde van diversiteit op kampus) leef. Benewens die uitbeelding van die studentekultuur, was daar in die studente se parodieë ook heelwat verwysings na die historiese milieu waarvan hulle deel vorm. Verder het heteroglossia (kodewisseling, veeltaligheid, dubbelstemmigheid), multikulturele humor en verskeie manifestasies van kreatiwiteit voorgekom, byvoorbeeld postmoderne metafiksie, divergente denke, sinergie in groepe, en 'n spel met grense in woorde en situasies. Uiteindelik kon ook verskillende voorbeelde van sogenaamde vroulike en manlike humorvoorkeure geïdentifiseer word.

'n Aantal studente het van die materiaal wat ek in die klas as voorbeelde gebruik het vir hul lesse benut, maar tog hul eie kombinasie en variasie op dieselfde tema geskep. Baie van die studente het hul eie inisiatief gebruik en ander materiaal aangewend. Een student het daaraan gedink om die leerders hul eie humoristiese tekste te laat klas toe bring. 'n Ander student het 'n jooltydskrif van die Universiteit van Kaapstad by haar onderrigprogram ingesluit. Verder het dit geblyk dat humor uit die massamedia baie bruikbaar is, omdat studente benewens koerante ook CD's en video's van bekende komediante en skrywers gebruik het.

Wat die webgebaseerde rolspeldebat betref, was die studente oor die algemeen van mening dat die anonimiteit in die virtuele konteks dit vir hulle moontlik gemaak het om te redeneer sonder om voortdurend op ander se gevoelens ingestel te wees (vgl. Bell, 2001; Lynch, 2004). Hulle kon karakters (as stereotipes) aanval, en nie mense nie. Hierdie reaksies van die onderwysstudente is in ooreenstemming met Lynch (2004:120-121) se uiteensetting van die elemente van virtuele rolspel. Die deelnemers het dus in die rol (persona) wat hulle gespeel het 'n masker gekry om te dra. Deur anonieme rolspel het hulle die vryheid verwerf om deel te neem, terwyl hulle dalk andersins (in 'n kontaksituasie) geïnhibeer sou voel of sou stilbly, en nie maklik sou agterkom wat hulle self dink nie. Dit blyk dus dat humoristiese tekste met groot vrug geïntegreer kan word vir die ontwikkeling van die taaluitkomste wat wentel om denke en redenering, en dat dit kreatiwiteit stimuleer (vgl. McGhee, 1979).

Een student wat groot waardering vir die kletskameraktiwiteit gehad het, wou weet hoe 'n mens dieselfde effek kon bereik in 'n klaskamer waar daar geen rekenaar is nie. Volgens my kan leerders ook as werklike rolspelers in gewone situasies van dramatisering gebruik word, met of sonder die maak van video-opnames. Dit is ook moontlik om hierdie tegniek suksesvol by debatsaande te gebruik. Op dié wyse kan groepe leerders saamdink oor argumente, met 'n segpersoon wat gekies word om op die verhoog namens die groep op te tree.

'n Student wat nie sy rol kon inneem gedurende die debat nie as gevolg van buitemuurse verpligtinge, het ná die tyd 'n harde kopie van die hele debat gelees en aan my sy refleksie en voorbereiding vir deelname per e-pos aangestuur. Ek beskryf hierdie refleksie in meer besonderhede, aangesien daar heelwat besprekingspunte aangeraak en kwessies aangespreek 
word wat relevant vir die gebruik van soortgelyke kletskamers deur taalonderwysers is (Kruger, 2006a:197). Verder kan ek as taalopvoeder (fasiliteerder) met hierdie sienings identifiseer (saamstem) en ek meen dat dit belangrike implikasies van die integrasie van humoristiese tekste deur middel van die rekenaar en 'n virtuele rolspeldebat (aan die hand van gesimuleerde, stereotipiese persona) in die taalonderrigkonteks uitspel.

In sy refleksie maak die student melding van 'n koerantartikel in Die Burger (Merton, 2004) oor 'n matriekseun wat geweier het om 'n Harry Potter-vraag in sy Engels-eindeksamen te beantwoord, omdat dit met sy Christelike geloofsoortuiging (sou) bots. Volgens hierdie student is die hele intydse Harry Potter-gespreksforum, waar leerders opsetlik moes haaks wees, dus relevant, sonder om so (gevaarlik) problematies te wees. Harry Potter kan bloot as vertrekpunt dien met opinies wat na fiktiewe personas getransponeer kan/moet word. Daarby is die student van mening dat die inhoudelike van die boekereeks dus nie onder die loep geneem hoef te word deur diegene wat nie die teks self wil bestudeer nie. Inteendeel, die leerders wat sterk teén Harry Potter en sy trawante gekant is, sal juis aan die debat wil en kan deelneem. As gevolg van die gewildheid van die Harry Potter-reeks sal die meeste kinders terselfdertyd in hul element wees. Die bruikbaarheid van kontroversiële (dog populêre) jeugtekste in die taalonderrigsituasie is dus onderstreep deur integrasie van studente se eie humoristiese tekste (deelname aan die debat) in die virtuele kletskamer.

Alhoewel die student nie self aan die forum deelgeneem het nie, was hy wel bewus daarvan dat die onderwyser goed sal kan monitor wat (en deur wie) alles gesê is en word. Hy sal egter vooraf moet seker maak (en deurgee) wat alles geassesseer (gaan) word. Vir hom is die vraag egter: Moet 'n mens iemand wat meer boodskappe (vinniger) 'post' (en so die debatte lewendig hou) met punte beloon, of eerder die konsensieuse leerder wat elke boodskap sorgvuldig deurlees (onder andere vir tikfoute)? Die medium vereis noodwendig spoed en 'veroorsak' foute (sic, student se doelbewuste tik-/spelfout). Verder wonder die student of leerders beloon moet word vir getroue karakterisering (deur middel van woordgebruik en swak, eensydige debatvoering), of vir goeie, rasionele standpunte. Nog ' $n$ vraag is of leerders uit hul infopakkies moet aanhaal, en of dit slegs as vertrekpunt gebruik moet word.

Die student is van mening dat die onderwyser as 'n uitstekende fasiliteerder van dié debat sal kan optree en dit enige tyd in 'n ander rigting kan stuur. Ook bied die opbrengs van hierdie oefening ' $n$ ruim seleksie aan materiaal wat onder meer bruikbaar is vir redigeringsoefeninge of die uitlig van debatskenmerke (soos blyk uit die harde kopie). Verder kon hierdie student hom indink aan die geskater van leerders wat besef dat hulle hul werklik kan inleef en -skryf in 'n karakter en/of standpunt. Buiten die integrasie met tegnologie word die kritieke uitkomste en demokratiese oogmerke volgens hierdie student dus bereik.

Om die studente in die onderrigprogram te laat reflekteer, was nie my hoofdoelwit nie - dit was 'n neweproduk om hulle in die proses van onderrig ook toe te rus om reflektiewe praktisyns te word, soos wat die 'Norms and standards' (Staatskoerant, 2000) van onderwyseropleiding verwag. Dit was as leerervaring gestruktureer om die fases van Kolb se proses van ervaringsleer in te sluit, naamlik ervaring, refleksie, teoretiese integrasie en aksie. Terselfdertyd was dit ook bedoel as triangulasie om die data wat ek beskryf, te verifieer. Die vrae wat aan die begin van die onderrigprogram (in April 2004) ingesluit is, was onder andere (invulvrae sowel as spasie vir kommentaar) om te reflekteer oor die week se aktiwiteite en melding te maak van hul waarnemings van klasgebeure en interaksie, asook om hul gevoelens en gedagtes daaroor uit te spreek en hul interpretasie van die opvoedkundige waarde daarvan te gee. 
Toe ek daarvan bewus geraak het dat die studente dit moeilik vind om die opdrag so 'oop' (ongestruktureerd) uit te voer, het ek een week ook meer spesifieke vrae gevra om die proses te fasiliteer, naamlik:

- Kies en omkring drie woorde in 'n kolom wat gevoelswoorde bevat (byvoorbeeld opwindend, moeilik, lekker, vervelig, ontspanne, frustrasie, spanning, uitdaging, lewendig, interessant, nuuskierig) om jou ervaring van die limeriek-oefening te beskryf.

- Motiveer jou antwoord op die vorige vraag met voorbeelde uit jou ervaring van die lesgebeure.

- Hoe het jy die samewerking met 'n spanmaat ervaar? Kom jy agter dat dit vir jou beter/slegter is om saam met sekere mense te werk? Gee voorbeelde sonder om name te noem.

- In watter mate sal hierdie oefening jou onderrig van Afrikaans in die praktyk beïnvloed?

- Watter idee(s) het by jou opgekom terwyl ons die oefening gedoen het?

- Hoe is idiome in die verlede aan jou onderrig? Hoe voel jy daaroor?

- Watter (nuwe) insig het jy gekry tydens die idioomlesse?

- Hoe het jy sedert die les oor idiome bewus geword van mense se gebruik van idiomatiese en/of figuurlike taalgebruik?

- Hoeveel beïnvloed jou persoonlike/akademiese/studentelewe jou ervaring van die lesse?

- Hoeveel beïnvloed die humoristiese tekste jou kreatiewe denke?

- Hoe sou jy die oefening(e) wysig as jy dit in jou eie onderrigpraktyk sou gebruik?

Om patrone te bepaal in die studente se skriftelike kommentaar op hul refleksie oor die onderrigprogram, het ek 'n tabel saamgestel (afgelei uit die antwoorde van die studente) om die frekwensie van elemente wat hulle genoem het, en moontlike oorheersende patrone vas te stel. Meeste van die studente het baie gedagtes uitgespreek in hul refleksie, terwyl een student geen geskrewe refleksiepapiere ingelewer het nie. Dit was duidelik dat die samehang van die lesse verlore gegaan het of moeilik integreerbaar was vir die studente indien hulle enkele klasse nie bygewoon het nie.

Enkele studente het verspreide opmerkings gemaak aangaande die estetiese en kulturele waarde van prente; idees vir groter projekte; die intimiderende effek van skriftelike refleksie; die nut van klasaantekeninge; 'n nuwe begrip van die verband tussen humor en kultuur; die moontlikhede vir die ontwikkeling van kreatiwiteit; kritiese geletterdheid en verbeelding in skole; die verband tussen die onderrigprogram en hul persoonlike lewe; 'n positiewe ervaring van samehorigheid in die klasgroep; waardering vir die variasie in tekste, aktiwiteite en opdragte; vergelyking van die onderrigprogram met hul ervaring van ander vakke (modules); hoe hulle voorberei en gemotiveer is vir die skryf van die parodie, en hul waardering vir die vryheid en stimulasie om self te dink. Heelwat studente $(40 \%)$ het melding gemaak van 'n nuwe bewuswording van die waarde van groepwerk en sinergie in die onderrigprogram, die invloed van humor op hul eie emosionele gemoedstoestand en die waarde van humor as spel.

'n Opsomming van die oorheersende patrone (meer as 50\% van die opmerkings) wat na aanleiding van die ontleding van die frekwensies in die tabel na vore kom, is die volgende: 
- nuwe idees vir eie onderrigprogramme en klaskamerpraktyk het ontwikkel as gevolg van die humoristiese tekste en aktiwiteite;

- gedagtes oor eie optrede en vaardighede word verwoord;

- nuwe begrip vir die waarde van pikturale humoristiese tekste blyk duidelik;

- die humoristiese tekste en aktiwiteite het gelei tot bewuswording van studente se eie kreatiwiteit;

- die opvoedkundige waarde van die integrasie van humor in taalonderrig word krities bevraagteken;

- waardering vir die effektiwiteit van die aanbiedingswyse word uitgespreek.

Sake wat in die groeps refleksie aansienlike reaksie uitgelok het, was die ontdekking van die bruikbaarheid van pikturale humor en die kreatiewe skryfmoontlikhede van die limeriek en die parodie. Dit het geblyk dat die mondelinge onderhoudsgesprek vir die studente waardevol was; veral die feit dat die integrasie van humoristiese tekste in 'n breër kulturele konteks geplaas en as deel van die hele onderrigprogram aangebied is. In die antwoorde op die gestruktureerde refleksievrae het twee studente opgemerk dat hulle dalk in hul eie onderrig by skole eerder met groepe van vier leerders sal werk wanneer limerieke geskryf word. Ander se reaksie was egter dat daar in so 'n geval te veel energie, individuele verskille en moontlikhede vir konflik bestaan wat eers opgelos moet word voordat die kreatiewe 'sap kan vloei'. Dit was ook duidelik dat nie almal se humorsin ooreenstem nie en dat versoenbaarheidsprobleme wat moontlik in groepwerk kan ontstaan, die kreatiewe proses kan inhibeer.

Tydens die groepsrefleksie het die studente melding gemaak van die waarde wat agtergrondinligting het om spotprente te interpreteer. Daar is ook genoem dat pikturale humor makliker herkenbaar is, omdat 'n mens dadelik die situasie deur middel van visuele leidrade kan opsom. Daarby is hulle van mening dat spotprente die leerders kan stimuleer om die meegaande berig in die koerant te lees, wat andersins moontlik nie sou gebeur nie.

\section{SLOTOPMERKINGS}

Dit is waarskynlik so dat baie onderwysers hul onderrig as 'n ernstige saak beskou en vermoed dat die integrasie van humoristiese tekste die leerinhoud sal vervlak. Daar is ook onderwysers wat voel dat hulle nie narre wil wees nie, terwyl ander glo dat hul humorsin nie genoegsaam ontwikkel is om dit in hul onderrigstrategieë te kan insluit nie. Tog is heelwat moontlikhede met beskikbare humoristiese tekste binne die meeste onderwysers se bereik.

Volgens Medgyes (2002:3) kan humor die kwaliteit van lewe en die proses van taalonderrig verbeter. Pollak en Freda (1997) stem saam dat die gebruik van humor in onderrig tot doeltreffende leer kan bydra. Die funksies van humor in die onderrig-en-leersituasie kan opgesom word as die opbou van verhoudings, bemagtiging van leerders, ontwikkeling van kreatiewe denke en stimulering van belangstelling, asook die vestiging van 'n goeie selfbeeld en sosialisering om houdings, motivering, leerder-outonomie en selfwerksaamheid te bevorder.

Tydens die professionele opleiding van taalonderwysers behoort leerders hul in te oefen in die gepaste taalgebruik binne lewensgetroue kontekste. Ook moet hulle taal kreatief leer gebruik, onder meer om aan hul verbeelding uitdrukking te gee vir die voorstelling en verkenning van menslike ervarings. Leerders moet terselfdertyd krities met 'n wye verskeidenheid tekste kan omgaan, en kultureel en esteties sensitief wees (Departement van Onderwys, 2002; 2003). 
Die navorsingsprogram het aangetoon hoe parodieë as kreatiewe uiting deur onderwysstudente geskryf kan word ná blootstelling aan verskillende soorte humor, en watter temas in studente se werk gevind sou kon word. Die parodieë wat in die onderrigprogram geskryf is het 'n intertekstuele digtheid getoon, met nabootsing en verwringing van die oorspronklike teks vir satiriese doeleindes. 'n Verskeidenheid stylmiddele is gebruik - van dubbelsinnigheid en klankspel tot oordrywing en inkongruensie, asook verwysings wat 'n dubbele stel seine genereer: een wat die oorspronklike teks oproep en die ander wat 'n spel daarmee aangaan. Hierdie spel het aanleiding gegee tot literêre kreatiwiteit, hoewel nie al die stories parodieë geword het nie. Een van die parodieë is wel opgeneem en gepubliseer in 'n literêre tydskrif (Müller, 2006). Verder het die vroulike studente en ook die manlike student gebruik gemaak van sowel vroulike as manlike humorvoorkeure in hul parodieë. Terwyl daar gespot is met die swakhede en uitspattighede in die samelewing waarbinne die studente hul bevind, het die skryf van beide die limeriek en die parodie ${ }^{4}$ as literêre stylfiguur vir aspiranttaalonderwysers die moontlikheid gebied om op 'n kreatiewe manier kommentaar te lewer, waar hulle dalk andersins nie die moed sou hê om so uitgesproke te wees nie (vgl. Kruger, 2006b).

In taalonderrig kan die rekenaar suksesvol vir sowel huistaal en addisioneletaal gebruik word in die vorm van interaktiewe rekenaarondersteunde taalonderrigprogramme, as vir deelname aan virtuele (webgebaseerde) rolspeldebatte. Internettegnologie, soos byvoorbeeld blognetwerke wat as virtuele kletskamers gebruik kan word, maak dit vir taalonderwysers toenemend moontlik om humoristiese tekste met die onderrigsituasie te integreer.

Die navorsingsprogram het duidelik getoon dat die integrasie van humoristiese tekste in die onderrig van Afrikaans kan bydra tot die professionele opleiding van taalonderwysers en die toepassing daarvan in taalklaskamers. Studente is deur die program aangemoedig om hul eie (en leerders se) humorsmaak te leer ken en waardeer, ander se humorsin te aanvaar en respekteer, en hulleself te omring met humor deur middel van video's, klankopnames, vertonings van komediante, spotprente in tydskrifte en op televisie. Dit het vir die studente as 'n aansporing gedien om self meer dikwels te lag en grappe of humoristiese anekdotes te vertel. Terselfdertyd is die studente toegelaat om hul grappe en snaakse ervarings onderling te deel, en met taal te speel deur self dubbelsinnighede ('puns'), alliterasie, assonansie en rymwoorde te skep.

Verder is die onderwysstudente in die onderrig- en navorsingsprogram gestimuleer om humor in die alledaagse lewe raak te sien deur te let op die ongewone, ongerymde, absurde, en onverwagte in gewone situasies. Hulle is aangemoedig om dit met ander te deel deur hulself te wees, vanuit 'n minder ernstige perspektief te kyk na wat hulle dink en sê, en te lag vir hul eie doen en late. Die prikkeling om humoristiese tekste in die klaskamer te integreer het gepaard gegaan met die verwerwing van insigte soos om aanstootlike humor te vermy en sensitief te wees vir emosionele studente en plofbare situasies.

Sodanige onderrigprogramme kan bydra om van humor 'n instrument en onderrigstrategie te maak waarmee inligting oorgedra kan word - humor as sodanig hoef dus nie die primêre doelwit van die les te wees nie. Taalonderwysers kan toepaslike humoristiese tekste integreer om opvoedkundige inhoude oor te dra, of hulle kan humoristiese tekste by uitdeelstukke en toetse voeg. Deur bewus te wees van sosiale inhibisies kan hulle dit deur middel van humor relativeer. Vraelyste om leerders se humorvoorkeure in die vorm van humorbelangstelling, style en -gebruik te identifiseer (vgl. Kruger, 2006a), kan vindingryk deur taalonderwysers aangepas, verfyn en gebruik word om hulleself en hul leerders beter te verstaan. 
In hierdie artikel het ek aangetoon dat humoristiese tekste suksesvol in die onderrig van Afrikaans geïntegreer kan word. Die wyer betekenis van die navorsing is dat ek deur die integrasie van humor as onderrigmateriaal aangetoon het dat die professionele ontwikkeling van aspirantopvoeders enersyds daarby kan baat, en dat dit andersyds in die skool (deur die praktiese toepassing daarvan deur onderwysstudente tydens hul skoolbesoeke) kan bydra tot 'n doeltreffende ontwikkeling van leerders se kreatiwiteit en kritiese taalgebruik in die onderrig van die Afrikaanse taal en letterkunde.

Benewens dat hierdie ondersoek waardevol blyk te wees vir taalonderwysers, taalleerders en in onderwyseropleiding, is daar enkele tekortkominge wat ek vervolgens wil aantoon. Alhoewel my studie herhaalbaar is, is daar verskeie faktore wat in die navorsingsprogram na vore kom wat nadere bestudering benodig, veral die verband tussen vroulike en manlike humorvoorkeure - juis omdat so 'n groot deel van die onderwyserskorps uit vroulike persone bestaan, terwyl die leerders in die skole seuns sowel as dogters insluit (vgl. Ziv, 1984).

'n Ander aspek wat verdien om verder bestudeer te word, is hoe die integrasie van humoristiese tekste kan bydra tot die oplossing van dissiplineprobleme in die klaskamer. Hierdie artikel toon wel aan dat die integrasie van humoristiese tekste positiewe gebruiksmoontlikhede kan hê juis omdat dit 'n manier is om leerders toe te laat om te speel met taal en hulle rebellie kreatief te kanaliseer. Dit is egter ook moontlik dat onderwysers of leerders se humorwaardering en -ekspressie aanstootlik kan wees vir die ontvangers daarvan of dat die verstaan in die resepsie daarvan nie plaasvind nie en die ontvangers of deelnemers geïntimideer of uitgesluit word. Die gevare wat aan die integrasie van humoristiese tekste verbonde is, is dus nie voldoende verken en verreken in hierdie artikel nie.

Ook die ontwikkeling van kreatiewe skryf as produk van taalonderrig met die integrasie van humoristiese tekste verdien meer aandag. Benewens dat daar moontlikhede is vir kreatiewe ekspressie, veronderstel die prosesbenadering wat gevolg is dat die onderriggewer die kreatiewe proses verstaan en dat daar voldoende tyd daarvoor in die onderrigprogram ingeruim moet word. Oor hierdie aspek kan meer navorsing gedoen word, alhoewel dit moeilik is om kreatiwiteit te meet en te assesseer.

Humoristiese tekste sou ook in verdere studies geïntegreer kan word om kritiese taalbewustheid in beide Afrikaans as huis- en addisioneletaal te ontwikkel (vgl. Telles, 2000:254) om tekstuele linguistiek te bevorder (Nash, 1985; Barbe, 1995; Vosloo, 2003), sowel as om die (kulturele) aspekte van humor as sosiolinguistiese verskynsel te bestudeer (Calitz, 1979; Verster, 2003).

Alhoewel hierdie artikel verwys na kontekstuele faktore soos die onderwysbeleid, kultuurmanifestasies soos Generasie $\mathrm{X} / \mathrm{Y} / \mathrm{Z}$ (lees: millenniërs), adolessente as deel van 'n verbruikersamelewing en addisioneletaal-leerders se konteks, is krities-opvoedkundige perspektiewe nie toereikend aangeraak nie. In ander of opvolgstudies kan meer navorsing gedoen word oor die integrasie van humoristiese tekste in kulturele konteks en of dit leerders of onderriggewers kan bemagtig om diversiteit en inklusiwiteit in die taalklaskamer te bevorder (Lovorn, 2008). Ook navorsing gebaseer op resepsie-ondersoeke (Ghesquiere, 1993a; 1993b; Joubert, 2002; Snyman, 2006) kan bydra tot inligting wat die ontwikkeling van taalonderwysers se verstaan van skoolgaande (adolessente) lesers se waardering van humor in jeug- en volwasse literêre tekste kan bevorder. Op hierdie terrein is reeds waardevolle navorsing oor tekste en lesers in die intermediêre en seniorfase gedoen (Van Niekerk, 2001; 
Van Niekerk \& Van der Westhuizen, 2004), wat sou opgevolg kon word met soortgelyke ondersoeke aangaande adolessente leerders se humorvoorkeure.

\section{EINDNOTAS}

${ }^{1}$ Constructivism may be considered an epistemology (a philosophical framework or theory of learning) which argues humans construct meaning from current knowledge structures. These arguments about the nature of human learning guide constructivist learning theories and teaching methods of education. Constructivism values developmentally-appropriate facilitator-supported learning that is initiated and directed by the learner. This is the path through which educators (facilitators) wish to approach students in constructing meaning of new concepts. (http://en.wikipedia.org).

2 'n Onlangse briefwisseling in Die Burger (Ami, 31 Mei 2008; Vrolike Taalmens, 6 Junie 2008) toon die spanning tussen kykers oor Oom Oubaas se gebruik van idiomatiese uitdrukkings en gesegdes. Hierdie soort mediatekste kan met vrug geïntegreer word om klasdebat aan te moedig en leerders se belangstelling in en kennis van idiome te verbreed.

${ }^{3}$ SCAMPER-tegnieke vir ontwikkeling van kreatiwiteit (Flack, 1997:126-7): Substitute (vervang); Combine (kombineer); Adapt / Adjust (maak aanpassings); Modify (verander) / Magnify (vergroot) / Minimise (verklein) / Maximise (vermeerder); Put to other uses (gebruik vir iets anders); Eliminate (neem weg) / Elaborate (brei uit); Reverse (keer om) / Rearrange (herrangskik).

${ }^{4}$ Die studente se parodietekste en limerieke is elektronies beskikbaar by http://estelleke.wordpress.com.

\section{BRONNELYS}

ALDERMAN, DH \& EJ POPKE. 2002. Humor and film in the Geography classroom: Learning from Michael Moore's TV Nation. The Journal of Geography, 101(6):228239.

AMABILE, TM. 1983. The social psychology of creativity. New York: Springer Verlag.

AMI. 2008. Oom Oubaas verkrag taal. Die Burger, 31 Mei.

ANDERSON, JA. 1995. Toward a framework for matching teaching and learning styles for diverse populations. In: SIMS, R.R. \& SJ SIMS (Eds), The importance of learning styles: Understanding the implications for learning, course design and education. London: Greenwood Press. 99-78.

BABBIE, E \& J MOUTON. 2001. The practice of social research. New York: Oxford University Press.

BALDWIN, AY. 2001. Understanding the challenge of creativity among African Americans. Journal of Secondary Gifted Education, 11(3):121-125.

BAND, AJ. 1990. Swallowing Jonah: The eclipse of parody. Prooftexts, 10:177-195.

BARBE, K.1995. Irony in context. Amsterdam: John Benjamins Publishing Company.

BELL, M. 2001. Online role-play: Anonymity, engagement and risk. Education Media International, 38(4):252-260.

BELZ, JA. 2002. Second language play as a representation of the multicompetent self in foreign language study. Journal of Language, Identity, and Education, 1(1):13-39.

BERK, RA. 1998. Professors are from Mars, students are from Snickers. How to write and deliver humor in the classroom and in professional presentations. Wisconsin: Mendota.

BLACK, L. 1986. Kommunikatiewe taalonderrig, met spesiale verwysing na letterkundeonderrig en eksaminering. Klasgids, April:62-74. 
BLACQUIÈRE, A. 1989. Kommunikatiewe taalonderrig: Moontlikhede vir Afrikaans Tweede Taal. Klasgids, Mei:50-57.

BOTHA, L. 1989. Tweedetaalteorie vir die eerstetaalonderwyser. Per Linguam, 5(1):50-58.

BRYANT, J, P COMISKY \& D ZILLMANN. 1979. Teacher's humour in the college classroom. Communication Education, 28(2):110-118.

CARR, W \& S KEMMIS. 1986. Becoming critical: Education, knowledge and action research. London: Falmer.

CHIASSON, PE. 2002. Using humour in the second language classroom. The Internet TESL Journal, VIII(3). [Elektronies]. http://iteslj.org. [4 November 2003].

CLARK, JL. 1996. From tasking purposes to purposing tasks. ELT Journal, 56(3):280-288.

CODRINGTON, GT. 1998. Generation X: Who, what, why and where to? [Elektronies]. http://www.tomorrowtoday.biz/mindthegap. [ 8 September 2005].

. 1999. Multi-generational ministries in the context of a local church. M.Th-tesis. Pretoria: Universiteit van Suid-Afrika. [Elektronies]. http://www.youth.co.za. [8 September 2005].

COMBRINK, J. 1998. Kwinksinnig. Kaapstad: Tafelberg.

COMBRINK, L. 1996. Kulturele geletterdheid en multikulturele onderwys. Tydskrif vir Taalonderrig, 30(1):1-13.

COOK, G. 2000. Language play, language learning. Oxford: Oxford University Press.

CORNEW, C. 1995. "Paradoxia epidemica" in the art of Pieter Bruegel the Elder: An investigation into sixteenth-century parody. Ongepubliseerde MA-tesis, Universiteit van Suid-Afrika, Pretoria.

DAHL, R \& Q BLAKE. 1982. Revolting rhymes. London: Penguin Books.

DEPARTEMENT VAN ONDERWYS. 2002. Hersiene Nasionale Kurrikulumverklaring Grade R-9 (skole). Kaapstad: Departement van Onderwys.

. 2003. Nasionale Kurrikulumverklaring Grade 10-12 (skole). Kaapstad: Departement van Onderwys.

DE VOS, P. 2000. So skryf jy 'n limerick. [Elektronies]. http://www.storiewerf.co.za/. [9 Maart 2003].

DE VOS, P \& P GROBLER. 1999. Kat se blad. Stuitige strokies. Kaapstad: Human \& Rousseau.

DU PREEZ, R \& JJH SCHOLTZ. 2004. Die verskillende dimensies van verpakking: 'n Toepassing op Generasie X en Y se kosmetiekaankope. Management Dynamics, 13(1):25-33.

EBERLE, B. 1982. Visual thinking: A SCAMPER tool for useful thinking. Buffalo, NY: D.O.K.

ERMARTH, ED. 1999. Finger exercises: Parody as a practice for postmodernity. European Journal of English Studies, 3(2):226-240.

GARNER, JF. 1994. Politically correct bedtime stories. London: Souvenir.

GENETTE, G. 1997. Palimpsests. Literature in the second degree. Lincoln: University of Nebraska Press. 
GHESQUIERE, R. 1993a. Het verschijnsel jeugdliteratuur. Leuven: Acco.

GHESQUIERE, R. 1993b. Leesbeesten en kijkcijfers: ondersoek naar het leesgedrag van Vlaamse jongeren tussen 9 en 15 jaar. Averbode: Altiora.

GROBBELAAR, PW \& W JORDAAN. 1980. Bietjie baie bogtery. Kaapstad: Tafelberg.

HOWARD, BC, S MCGHEE N SCHWARTZ \& S PURCELL. 2000. The experience of constructivism: Transforming teacher epistemology. Journal of Research on Computing in Education, 32(4):455-465.

HUTCHEON, L. 1985. A theory of parody. London: Methuen.

IP, A, R LINSER \& S NAIDU. 2001. Simulated worlds: Rapid generation of web-based roleplay. [Elektronies]. http://ausweb.scu.edu.au/. [8 Oktober 2005].

JOUBERT, MM. 2002. Die leesbelangstellings en leesgewoontes van Afrikaanssprekende tienderjariges in Pretoria. Ongepubliseerde Meestersverhandeling, Universiteit van Suid-Afrika, Pretoria.

KAMWANGAMALU, NM. 1997. English and transformation to multicultural education in the new South Africa. Journal for Language Teaching, 31(2):243-252.

KHER, N, S MOLSTAD \& R DONAHUE. 1999. Using humor in the college classroom to enhance teaching effectiveness in 'dread courses'. College Student Journal, 33(3):400406.

KIRSH, GA. \& NA KUIPER. 2003. Positive and negative aspects of sense of humor: Associations with the constructs of individualism and relatedness. Humor, 16(1):3362.

KOLB, D. 1984. Experiential education: Experience as the source of learning and development. Englewood Cliffs, NJ: Prentice Hall.

KRISH, P. 2001. A role play activity with distance learners in an English language classroom. The Internet TESL Journal, VII(7): Julie. [Elektronies]. http://iteslj.org/. [26 November 2004].

KRUGER. E. 2001. Die insluiting van 'n (multi-)kulturele komponent in die kurrikulum van Afrikaans as addisionele taal. Literator, 22(3):75-91.

. 2003. Harry Potter (I): Motivering vir die insluiting in die onderrig van Afrikaans. Tydskrif vir Taalonderrig, 37(2):179-196.

. 2006a. Die gebruik van humormateriaal in die onderrig van Afrikaans. Ongepubliseerde PhD-proefskrif, Universiteit Stellenbosch.

. 2006b. Onderwysstudente se parodieë as hibridiese tekste: 'n navorsingsverslag. Literator, 27(2):83-108.

. 2007a. Die ontwikkeling van 'n rekenaarondersteunde taalonderrigprogram op grond van Afrikaanse folklore. Per Linguam, 23(1):16-29.

. 2007b. Die onderrig van millenniërs in die Afrikaans-klaskamer: Humormateriaal as onderrigstrategie. Tydskrif vir Taalonderrig, 41(2):47-68.

. 2008. Die verband tussen konstruktivistiese beginsels en taalonderrig: ontwikkeling van 'n navorser se eie epistemologie. Acta Academica. In pers.

LATHER, P. 1986. Issues of validity in openly ideological research: Between a rock and a soft place. Interchange, 17(4): 63-84. 
LIEBOWITZ, J. 2002. Teach people skills totally online? College Teaching, 51(3):82-85.

LOCHNER, M. 2005. Slypskool vir visuele woordkuns aangebied in Durbanville op 16 April.

LOVORN, M. 2008. Humor in the home and in the classroom: The benefits of laughing while we learn. Journal of Education and Human Development, 2(1):1-12.

LYNCH, MM. 2002. The online educator: A guide to creating the virtual classroom. New York: RoutledgeFalmer.

. 2004. Learning online: A guide to success in the virtual classroom. New York: RoutledgeFalmer.

LYTTLE, J. 2001. The effectiveness of humor in persuasion: The case of business ethics training. Journal of General Psychology, 128(2):206-216.

MCGHEE, PE. 1979. Humor: Its origin and development. San Francisco: W.H. Freeman.

MARTIN, A, S LEBERMAN \& J NEILL. 2002. Dramaturgy as a method for experiential program design. The Journal of Experiential Education, 25(1):196-206.

McMAHON, M. 1999. Are we having fun yet? Humor in the English class. English Journal, 88(4):70-72.

MEDGYES, P. 2002. Laughing matters. Humour in die language classroom. Cambridge: Cambridge University Press.

MENKVELD, H. 1990. Geskrewetaalmoeilikhede met Afrikaans (Eerste Taal) by hoërskoolleerlinge: Fouteanalise en remediërende strategieë. Ongepubliseerde $\mathrm{PhD}$ proefskrif, Universiteit Stellenbosch.

MERTON, M. 2004. Harry Potter sorg vir herrie in matriekeksamen. Die Burger, 30 Oktober.

MINCHEW, SS. 2001. Teaching English with humor and fun. American Secondary Education, 30(1):58-70.

MOYO, T. 1997. Are the current high school literature texts of relevance of the culture of ESL learners? Tydskrif vir Taalonderrig, 31(1):42-49.

MURPHY, K \& Y GAZI. 2001. Role plays, panel discussions and simulations: Project-based learning in a web-based course. Education Media International, 38(4):261-270.

MÜLLER, A. 2006. O Griet, skryf 'n parodie. Literator, 27(2):215-219.

NASH, W. 1985. The language of humor. London: Longman.

NILSEN, AP \& DLF NILSEN. 1999. The straw man meets his match: Six arguments for studying humor in English classes. English Journal, 88(4):34-42.

PETERS, M. 2003. The use of the useless: All I really need to know I learned as a teaching artist. Teaching Artist Journal, 1(4):213-219.

PIENAAR, A. 2004. Die verband tussen kognitiewe buigsaamheid en humorsin by adolessente. Ongepubliseerde MSc-tesis, Universiteit van die Vrystaat.

POLLAK, JP \& PD FREDA. 1997. Humor, learning, and socialization in the middle level classrooms. Clearing House, 70(4):176-178.

PRETORIUS, R. 1992. Parodie. In: CLOETE, TT. (red.). Literêre terme en teorië̈. Pretoria: HAUM. 370-372. 
RAYBIN, D. 1990. Aesthetics, romance and Turner. In ASHLEY, KM (Ed.), Victor Turner and the construction of cultural criticism. Between literature and Anthropology. Bloomington: Indiana University Press. 21-41.

RIGDEN, R. 2001. Wildside. Kaapstad: Brigand Selections.

ROBERTSON, G. 1980. Kreatiwiteit. Ongepubliseerde studiegids vir afstandsonderrig, Natalse Onderwyskollege, Pietermaritzburg.

ROBINSON, GLN. 1995. Crosscultural understanding: Processes and approaches for foreign language, English as a second language and bilingual educators. New York: Pergamon Institute of English.

ROSE, MA. 1993. Parody: Ancient, modern, and post-modern. Cambridge: University Press.

RUCH, W. 1999. The perception of humor. [Elektronies]. http://www.uniduesseldorf.de/www/MathsNat/Ruch/Texte/Naplesl.doc. [6 November 2003].

RUGGIERI, CA. 1999. Laugh and learn: Using humor to teach tragedy. English Journal, 88(4):53-58.

RUSCIO, J, DN WHITNEY \& TM AMABILE. 1998. Looking inside the fishbowl of creativity: Verbal and behavioral predictors of creative performance. Creativity Research Journal, 11(3):243-263.

RUTKAUS, M. 1981. Use of humor in instruction. NSPI Journal: 17-19.

SACKS, P. 1996. Generation X goes to college: An eye-opening account of teaching in postmodern America. Chicago: Open Court.

SHADE, RA. 1996. License to laugh: humor in the classroom. Englewood, CO: Teacher Ideas Press.

SIMONNEAUX, L. 2001. Role-play or debate to promote students' argumentation and justification on an issue in animal transgenesis. International Journal of Science Education, 23:903-927.

SNYMAN, M. 2006. Die leesvoorkeure en leesgedrag van Afrikaanse kinders. Mousaion, 24(1):145-179.

STAATSKOERANT. 2000. Norms and Standards. Pretoria. Vol. 415. No. 20844.

THORSON, JA. 2002. Social values and decision making: A generation in the lifeboat. Death Studies, 26:343-355.

TOMPKINS, PK. 1998. Role playing / Simulation. The Internet TESL Journal, IV(8). Augustus. [Elektronies]. http://iteslj.org/. [10 Julie 2005]

TOROK, SE, R McMORRIS \& WC LIN. 2004. Is humor an appreciated teaching tool? Perceptions of professors' teaching style and use of humor. College Teaching, 52(1):14-20.

TORRANCE, EP. 1962. Guiding creative talent. Englewood Cliff, NJ: Prentice-Hall. 1970. Encouraging creativity in the classroom. Dubuqye, Iowa: Wm. C. Brown Company. . 2003. The millennium: a time for looking forward and looking back. The Journal of Secondary Gifted Education, 15(1):6-12. 
VAN NIEKERK, JE. 2001. Humor in kinderverhale: 'n vergelyking tussen geselekteerde Afrikaanse en Nederlandse tekste. Ongepubliseerde MA-tesis, Potchefstroom Universiteit vir $\mathrm{CHO}$.

VAN NIEKERK, JE. \& BE VAN DER WESTHUIZEN. 2004. Humor in kinderverhale in die tersiêre en intermediêre fases van taalonderwys. Literator, 25(3):151-179.

VERSTER, F. 2003. 'n Kultuurhistoriese perspektief op die pikturale humor van T.O. Honiball. Ongepubliseerde PhD-proefskrif, Universiteit Stellenbosch.

VOSLOO, J. 2003. Die manifestering van humor in geselekteerde Afrikaanse kortverhaaltekste. Ongepubliseerde D.Lit.-proefskrif, Universiteit Stellenbosch.

VROLIKE TAALMENS. 2008. Oom Oubaas vrolik taal op. Die Burger, 5 Junie.

WEBER, A. 2000. Playful writing for critical thinking: Four approaches to writing. Journal of Adolescent \& Adult Literacy, 43(6):562-568.

WES-KAAP ONDERWYSDEPARTEMENT. 2006. WKOD Geletterdheid- en syferkundigheidstrategie 2006-2016. Kaapstad: Wes-Kaapse Provinsiale Regering.

WHITE, GW. 2001. Teachers' report of how they used humor with students perceived use of such humor. Education, 122(2):337-347.

ZIV, A. 1984. Personality and sense of humor. New York: Springer.

\section{BIOGRAFIESE NOTA}

Estelle Kruger is 'n senior lektor en doseer Afrikaans-onderrig by die Fakulteit Opvoedkunde aan die Universiteit van Stellenbosch. Vir 'n M.A. het sy gespesialiseer in die onderrig van Afrikaans as addisionele taal (1996) en haar Ph.D. handel oor die gebruik van humormateriaal in die onderrig van Afrikaans aan onderwysstudente (2006). Tans doen sy navorsing oor die stimulering van verbeelding in die onderrig van kreatiewe skryfvaardighede, sowel as Afrikaanse jeugliteratuur en rekenaarondersteunde taalonderrig. (E-pos: ekruger@sun.ac.za). 